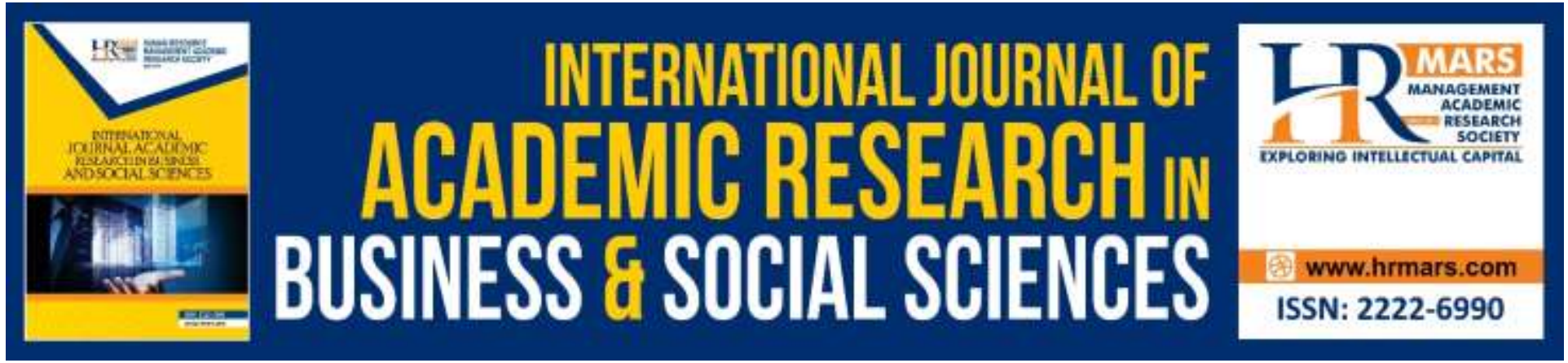

\title{
Indo- Pak Relation and Indus Water
}

Shahana Maryam, Mohamed Ali Bin Haniffa, Jazliza Binti Jamaluddin

To Link this Article: http://dx.doi.org/10.6007/IJARBSS/v9-i9/6481

DOI: $10.6007 /$ IJARBSS/v9-i9/6481

Received: 15 August 2019, Revised: 30 August 2019, Accepted: 01 September 2019

Published Online: 28 September 2019

In-Text Citation: (Maryam, Haniffa, \& Jamaluddin, 2019)

To Cite this Article: Maryam, S., Haniffa, M. A. Bin, \& Jamaluddin, J. B. (2019). Indo- Pak Relation and Indus Water. International Journal of Academic Research in Business and Social Sciences, 9(9), 1353-1362.

Copyright: (C) 2019 The Author(s)

Published by Human Resource Management Academic Research Society (www.hrmars.com)

This article is published under the Creative Commons Attribution (CC BY 4.0) license. Anyone may reproduce, distribute, translate and create derivative works of this article (for both commercial and non-commercial purposes), subject to full attribution to the original publication and authors. The full terms of this license may be seen at: http://creativecommons.org/licences/by/4.0/legalcode

Vol. 9, No. 9, 2019, Pg. 1353 - 1362

http://hrmars.com/index.php/pages/detail/IJARBSS

JOURNAL HOMEPAGE

Full Terms \& Conditions of access and use can be found at http://hrmars.com/index.php/pages/detail/publication-ethics 


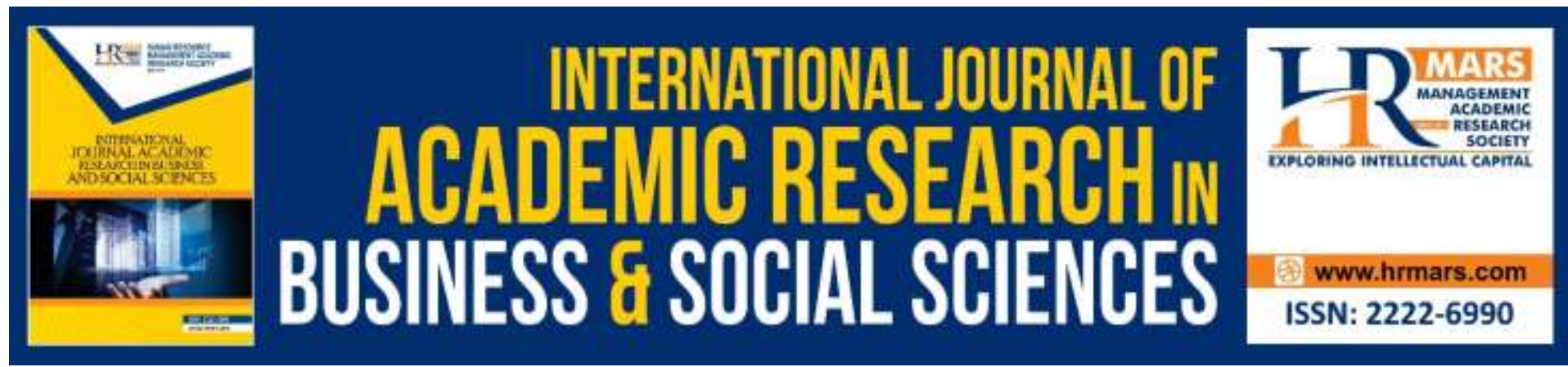

\title{
Indo- Pak Relation and Indus Water
}

\section{Shahana Maryam¹, Dr. Mohamed Ali bin Haniffa², Dr. Jazliza Binti Jamaluddin. ${ }^{3}$}

${ }^{1}$ Ph.D Scholar at School of Language, Civilization \& Philosophy, University Utara Malaysia (UUM), Malaysia, ${ }^{2}$ Deputy Director, Foundatin Center, University Utara Malaysia (UUM), Malaysia, ${ }^{3}$ Senior Lecturer at School of Language, Civilization \& Philosophy, University Utara Malaysia (UUM), Malaysia.

\begin{abstract}
Water has changed into a rigidly basic settling in the change strategy everything being equal. Not exclusively is anchored drinking water key for our flourishing, anyway water is in like way a crucial essential for encourage agrarian, ebb and flow and importance related redesigns. Normal for the Indus Water Treaty mean the entire of a basic and long-standing examination among India and Pakistan over water common contention, opens the course to the quiet utilize and progress of water assets on which depends the control of some place in the extent of 50 million individuals in the two nations. This paper looks into the 1960 Indus Waters Treaty (IWT) between the lawmaking assortments of India and Pakistan in setting of the new normal and social substances going up against water assets. In any case, one can't disregard the difficulties of future supplies of crisp water between the two nations.
\end{abstract}

Keywords: Pakistan, World Bank, Indus Waters Treaty.

\section{Introduction and Background}

Water is a typical resource which minds no local cutoff points. Water continues being an impulse for war and peace even in the twenty-first century. The standard availability of water has lessened for different components realizing augmentation of districts experiencing water lack, driving by and large to crisis. The rising level of masses is one of the principal drives for the rising enthusiasm for water especially in the making countries. This exploration attempts to comprehend the tussle amongst India and Pakistan over water by revealing insight over Indus Water Treaty and its suggestions. This research paper will illuminate the requirement for joint collaboration, shared water assets and viable administration of water with expanded complex. The water organization and scattering has been a great degree of inconvenient process in South Asian countries, whose economies are fundamentally agrarian and are liable to water resources. (Coscrove, 1999)

The rising danger as a result of consistently rising weights among India and Pakistan provoking an unsafe area in South Asia could in like manner be a stress, nonetheless, such chances of up close and personal standoff are low yet the peril of water transforming into a vital issue can't be slighted. Regardless, these issues can be tenderly overseen and not caught with control conflicts that sometimes do incorporate horrendous acts. The basic driver of water conflicts or war of words so far has been a result of the nonappearance of freshwater 
availability to deal with rising interest of masses improvement. In this century if the war of weapons is a hazard to worldwide security and power tantamount water wars are a threat to the economy. Conduits water conflicts transversely finished edges are hard to overcome and subsequently they should be painstakingly overseen. (Wolf, 1999)

At the time of partition the division of Punjab the main heads works of water remained in the India which caused the problem of sharing water between two new born states. The head works on the Sutlej River i.e Ferozepur while on the Ravi River the head works i.e Madhopur was further caused the Indus Water Treaty. For this purpose the first meeting between two nations was set on 20 December 1947. In this way, a between time assertion known as Delhi Agreement was set apart on 4 May 1948, according to which the waters would continue spilling out of India as a side-effect of portion by Pakistan. The statement in like manner settled India's rights on the conduits in East Punjab. (Nehru, 1961) ${ }^{1}$ Clearly beset, Pakistan on 16 June 1949 offered to take the inquiry to the International Court of Justice (ICJ), which India can't. This was the essential such move to search for circumspection and exhibited unequivocally that Pakistan would, at the fitting time, internationalize the issue and search for outcast mediation. On 10 May 1950, as a counter response, India enrolled the Delhi Agreement with the UN, while Pakistan repudiated its authenticity.

\footnotetext{
${ }^{1}$ Nehru was clarifying the channel water question amongst India and Pakistan on the event of the opening of the Nangal Canal on 8 July 1954. Nehru griped that the assertion touched base at in 1948 was not completely consented to by Pakistan. Pakistan, truth be told, condemned the assertion. Nehru likewise clarified how the World Bank wound up plainly required in interceding amongst India and Pakistan. The 1948 assertion had bound India to just bit by bit increment its off-take. The understanding was intended to be of an impermanent sort, however Pakistan procrastinated and furthermore dismisses the different proposition advanced by India and the World Bank in 1954. India chosen to resume its opportunity of activity on utilization of waters of waterways in East Punjab. In the long run, India's activity prodded Pakistan to go to the arranging table.
} 


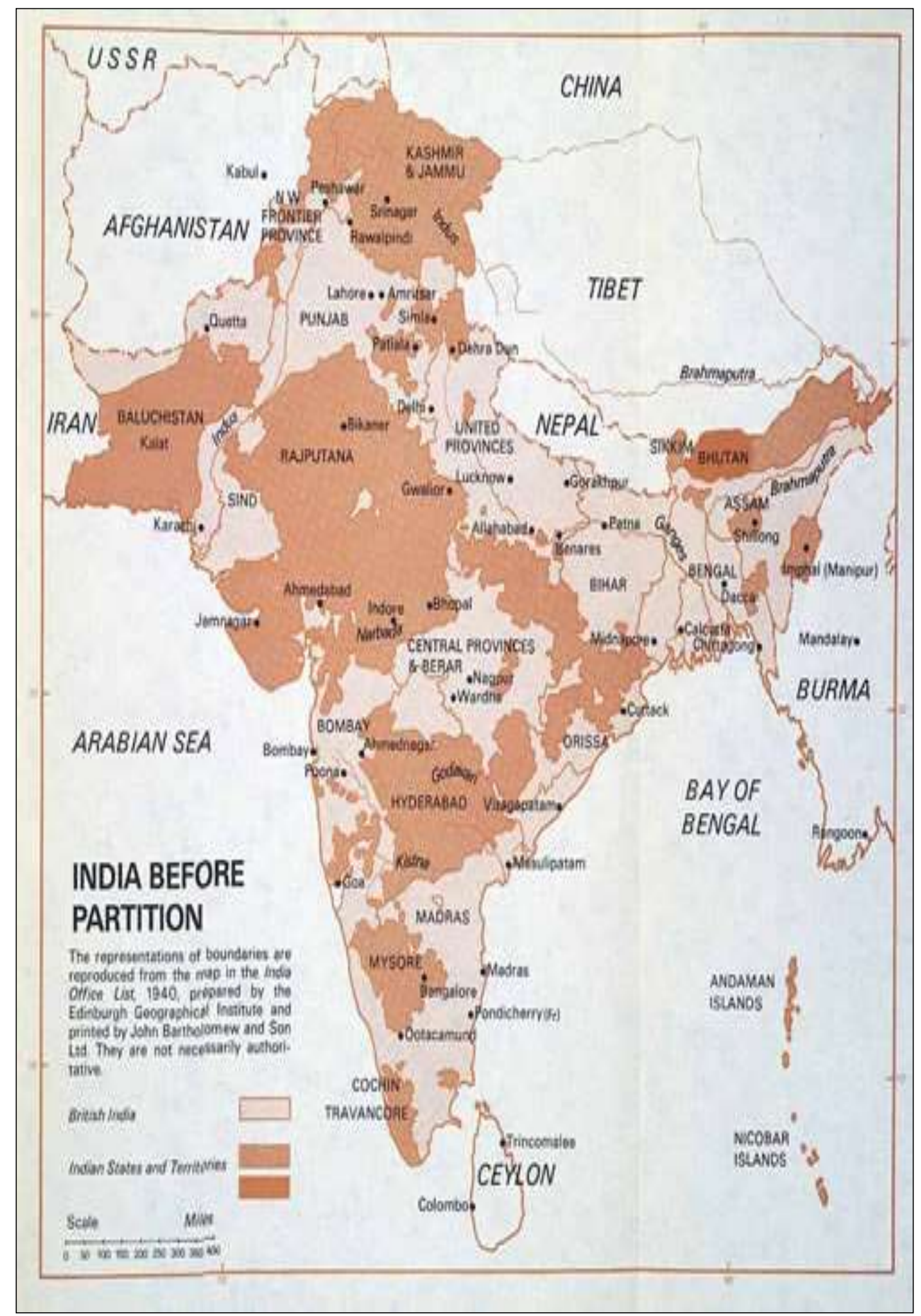

Figure 2.1. Map of India before Partition

The hostile vibe among two nations has its concealed foundations that further progression to get autonomy from the British. The focal denounce line kept running along religious base which puts both communities against each other. (Alam, 2002) The partition of India by the British created many problems. Specifically, the issue of Kashmir 
' has perseveringly aggravated by two nations.

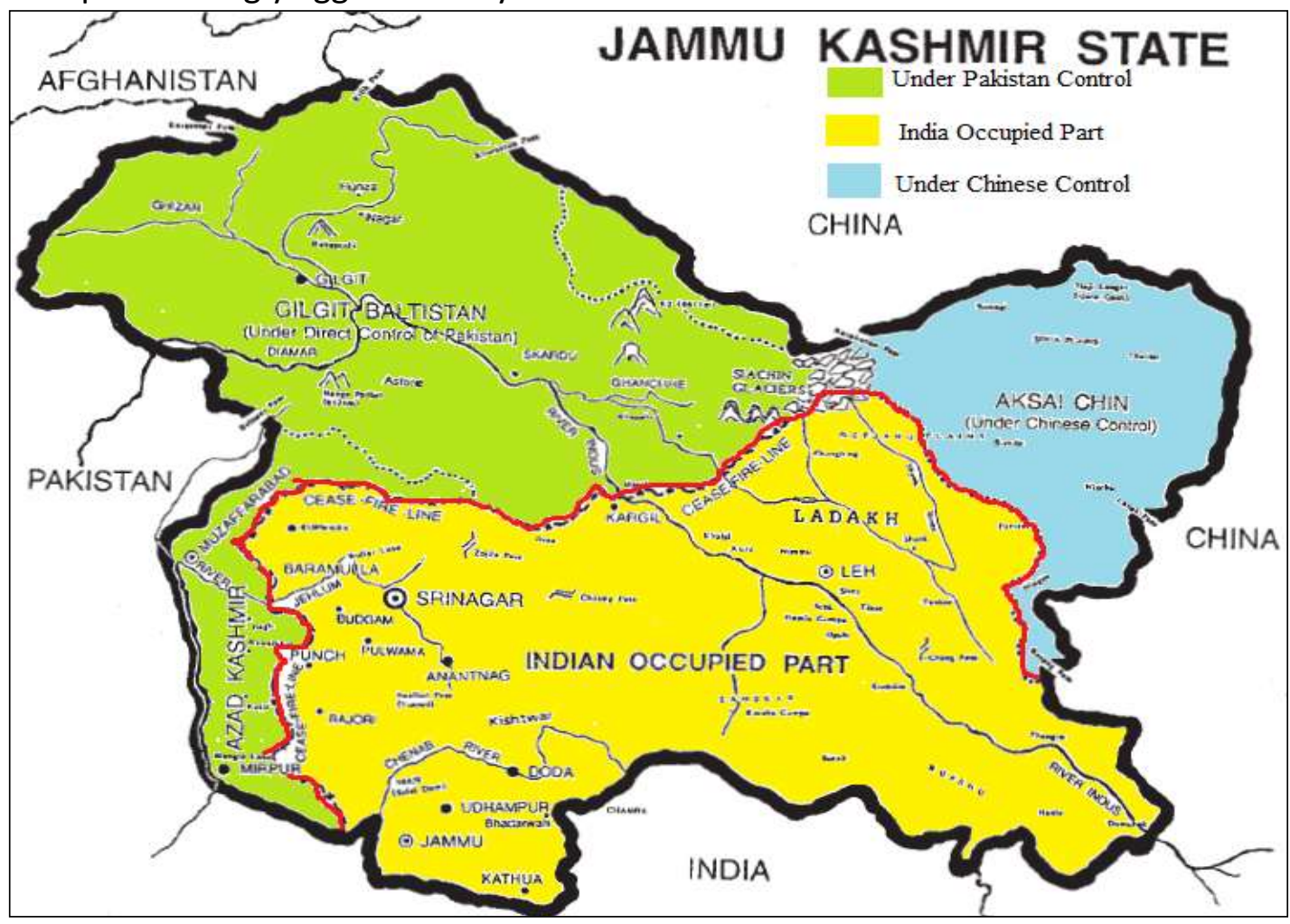

Figure 2.2 Map of Kashmir

\section{Indus Water Treaty}

South Asia radiates an impression of being a high-danger strife zone in the lexicon of world authoritative issues. What makes it a fundamental territory is its polemical state of intracommonplace issues and provoke security concerns. With various questionable issues around, it has for quite a while require a capable and result arranged peace arranged. Diverse frameworks and parameters are prescribed to decide such intra-regional conflicts. "Water in such way can be a particularly convincing measure to decide crisis and achieve peace. The South Asian countries are generally agrarian and a considerable measure of water is required for water framework to manage the rising people in this manner the rising enthusiasm for water is a run of the mill stress for the neighbors.

Water deficiency demands supportive and calm sharing of water across finished edges. The south Asian neighbors, regardless of sharing ordinary history, standing up to near social and fiscal befuddle and encountering a lone strategy of nation building, it is occupied with its intraregional prominent malevolencies that don't empower South Asia to beat its issues. (Tidwell, 1998) This is a direct result of how South Asia is unendingly tormented by various intra and between state conflicts and crisis originating from myopic attitudes of the, as it were, untalented masses and the lethargic approach of the choice tip top towards assurance of such issues. These exacerbates its photo furthermore adds to the destabilization of the range in the overall eyes. In spite of all odds and contrasts, Indus deal tries to create sign of look for after neighbors to team up to decide crisis. (Chakraborty, 2002)

The Partition of India in 1947 portion isolated the Indus structure between the two as of late made nations of the subcontinent. There had been a critical water framework change in bound together Punjab in light of Indus waters system, which got annoyed with the portion. 
"At fragment in 1947, as far as possible among India and West Pakistan cut the water framework course of action of Bari Doab and the Sutlej Valley expand, at first sketched out as one arrangement, into two areas. The headwork tumbled to India while the conduits experienced Pakistan. It achieved unsettling influence in the water supply in a couple of segments of Pakistan". (Chakraborty, 2002)

MAP 1.1 The Indus Basin

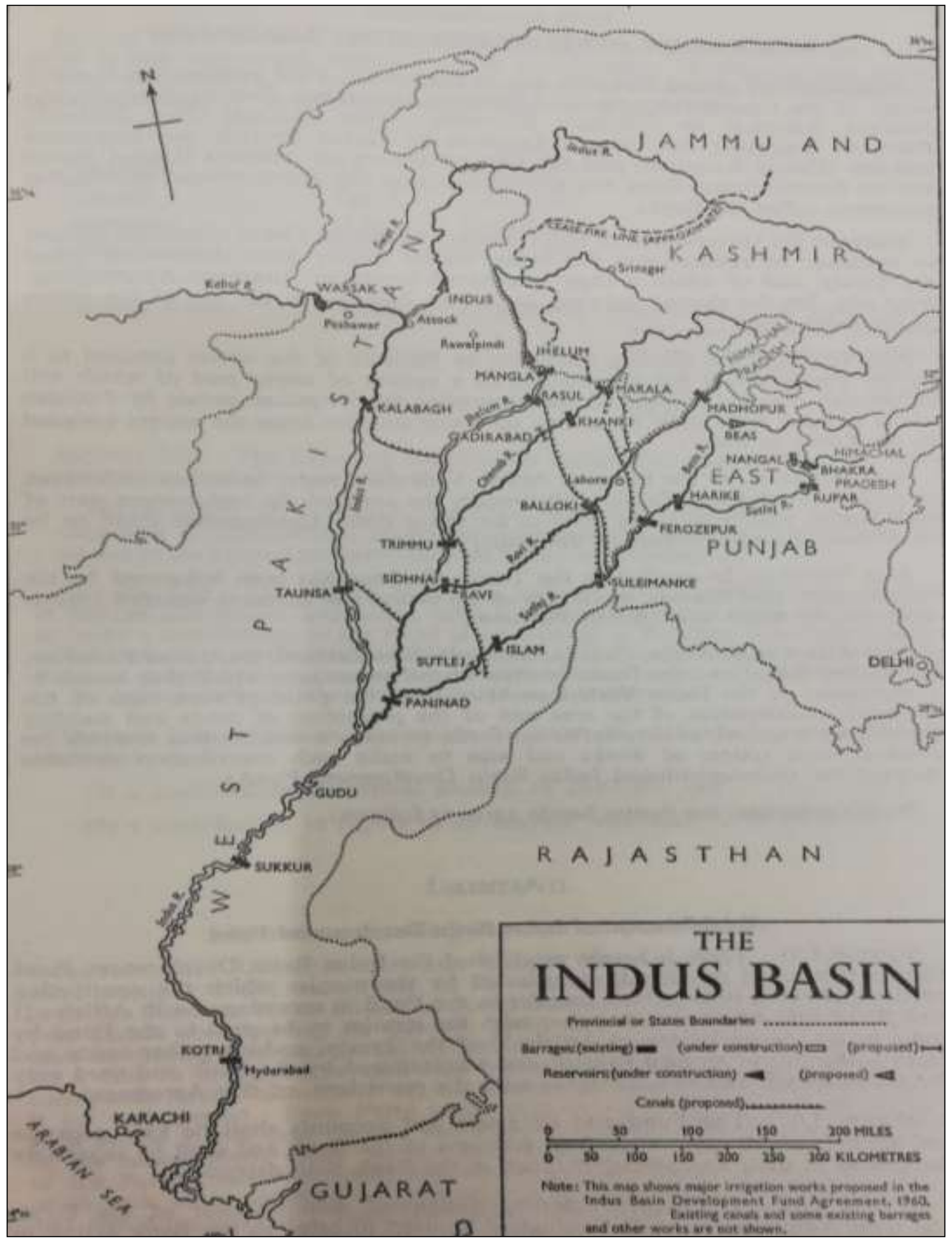

Source: File No. CO 111/641, The National Archive, United Kingdom 
After early on water sharing issue, the deal was set apart among India and Pakistan through accommodating mediation and help of World Bank in Sep 1960, entitled "The Indus Water Treaty". ii The water sharing course of action under the game plan was exceptionally direct: the three western conduits (the Jhelum, the Chenab and the Indus) were disseminated to Pakistan with a couple of reservations and the three eastern streams (the Beas, the Ravi, and the Sutlej) were given to India. (Kalair, 2019 ) The Indus Basin broadens furthermore included improvement of Tarbela and Mangla dams. The wander was bolstered by the genuine forces including World Bank (the leading coordinated0, United Kingdom, New Zealand, Germany, United States, Australia and Canada.ii "The deal settled and delimited the rights and responsibilities of India and Pakistan in association with each other, concerning the usage of waters of the Indus course of action of streams". There were certain reservations set on both the countries with respect to the use of conduit waters. India has been using everything considered $33 \mathrm{MAF}$ of water from the eastern streams and has produced a couple of dams and surges to supply water to Punjab and neighboring states and has been pulling back waters from the western conduits for water framework reason as allowed under course of action. (Miner, 2009)

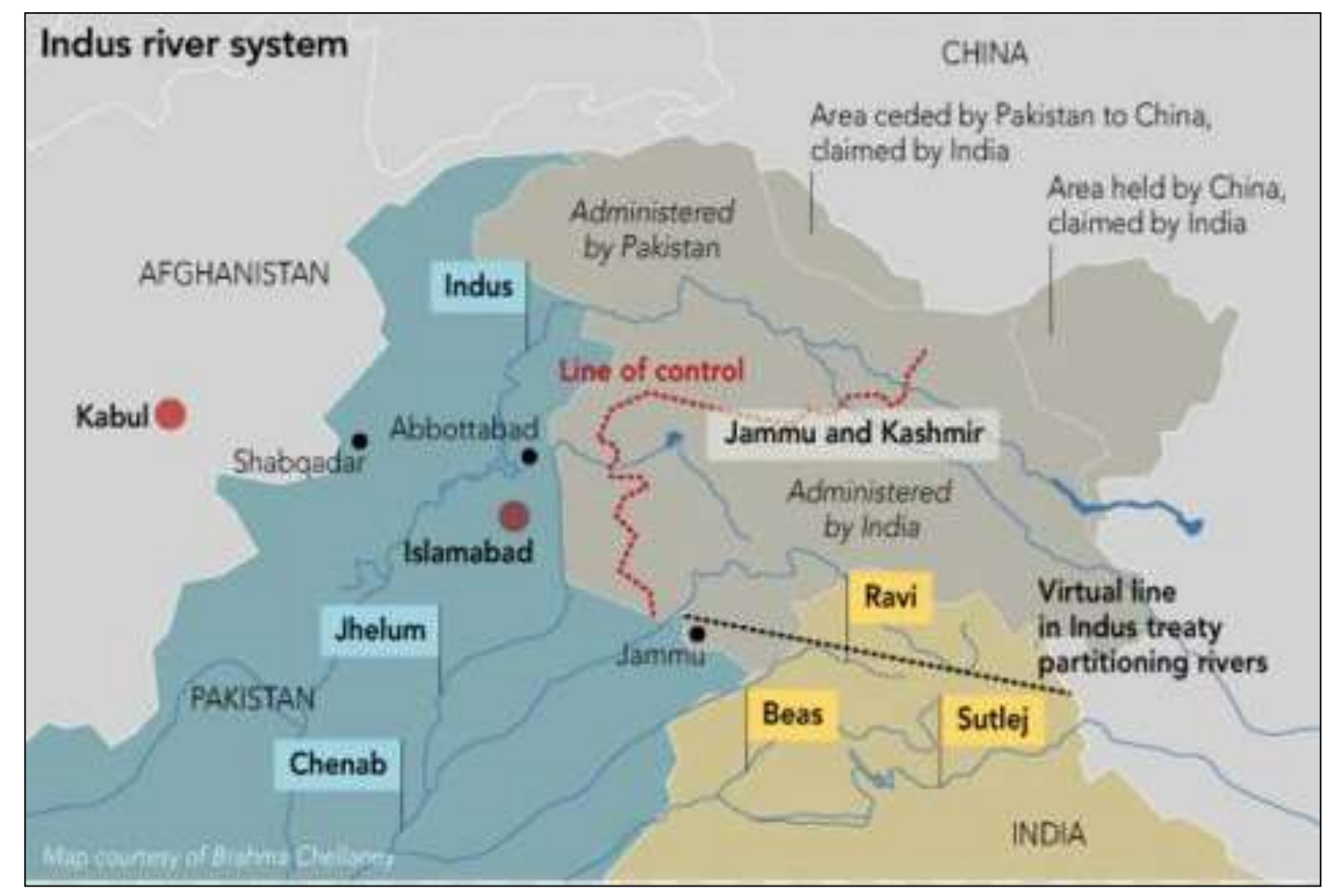

Figure 2.3. Indus River Sysytem

On Pakistan, the lower riparian there were for the most part lesser controls. Pakistan diverted water from its western conduits to supplant the principal water streams from eastern conduits. It in like manner has produced different new association trenches and dams to ensure suitable water supply. There were moreover plans in the settlement regarding the exchanging of data on wander operation, expansion of immersed cultivating and so forth, which is almost no versatile these days, checking the straightforwardness that existed among the two countries in sharing the conduits. The deal also requested certain institutional gameplans: An interminable commission on Indus Waters was made, with boss from the two India 
and Pakistan, going about as illustrative of their different governments for all issues rising out of the course of action.

The Indus System, the Indus, with its five essential tributary conduits, includes one of the monstrous stream structures of the world. Its yearly stream is twice that of the Nile and three times that of the Tigris and Euphrates united; it means pretty much 170 million segment of land feet, or enough water to submerge, to a significance of one foot, the whole domain of the State of Texas, or the whole area of France. Most of the six essential surges of the system climb in the high Himalayas. Supported transcendently by dissolving snow and ice and by them on storm downpours, they dive through the mountains and the slants on to the delicately slanting fields of West Pakistan and north-western India. Precipitation is meager in the field's zone, and without the streams, and the water framework system, the fields of the Indus bowl would be take off. In any case, with the game plan of water framework made over the span of the latest hundred years, the streams reinforce masses of around 40 million people in Pakistan and around 10 million in India-about one-tenth of the united people of the two countries. The locale of watered land is around 30 million areas of land. This is one of the greatest water framework systems on the planet; it reinforces a greater range than is overflowed in Egypt and the Sudan by the Nile. (Ali, 2008)

Up to now, the system has been made totally from conduit stream, and without vault amassing; in result, water supplies are precarious to the extent that they are liable to the customary assortments, and additionally to the year-by-year assortments, in the flood of the streams. There were conflicting water ensures reliably in banter between the Sind and Punjab domains of bound together India. Package drew the periphery among India and Pakistan perfect over the Indus structure. Pakistan transformed into the downstream riparian, and the head works of two of the guideline water framework conduits in Pakistan were left on the Indian side of the periphery. The sharing and use of the waters quickly transformed into an overall issue, and has been an essential purpose behind focused on relations among India and Pakistan. (Ali, 2008)

Hydroelectric power is a vital objective of water headways. At exhibit, it speaks to 70 to around 100 percent of all power made in countries as various as Brazil, Canada, Morocco, Norway and Sri Lanka. Hydropower has starting late ended up being engaging for a few countries, especially to the extent growing freedom and diminishing the national alter ofportions issue expedited by acquiring imperativeness conveying materials. While the capital costs for hydro headways are high, running costs are insignificant. In addition, period of energy does not consume water, which would then be able to be used for agrarian, present day and distinctive purposes. The potential for hydropower has been recognized, so to speak, in North America and Europe. Regardless, there is an immense potential holding up to be made in Africa, Asia and Latin America. Africa's hydro potential is the scarcest developed, its present yearly era being only 4.3 for every penny of the potential yield. Thus, in Africa, the example towards growing emphasis on hydropower time, in slant to various sorts of imperativeness change, is most likely going to continue for quite a while to come. Pakistan and India share not only a $1610 \mathrm{~km}$ periphery, vernaculars, support, garments direction and culture, moreover the waters from six courses: the Indus, Jhelum, Chenab, Ravi, Sutlej and Beas Rivers, close by their different tributaries. The creating peoples of the two countries and the resultant extended enthusiasm for water have influenced the sharing of Trans to restrain water dynamically puzzling. 


\section{Conclusion}

Water has reliably been a parameter for progression and being a typical resource has now made things more fundamental, particularly among the countries falling in completely dry/semi-dry land zones. This ceaseless competition close by control sharing differences among countries every now and again shows up as mental aggressor act, harming the human rights and undermining the security of district. Subsequently masterminding and authoritative system for sharing resources in an overall world has ended up being more erratic. These days we find security issues getting particularly associated with handy headway. This requires a multidisciplinary considering while in the meantime keeping an eye on such issues and encompassing critical methodologies and approaches.

Without a doubt the Indus Water Treaty includes pride for the two nations, adequately working even amidst an extensive variety of complexities. The lessons should be picked up from settlement. The placating exercises should be progressed and reasonable deals should be made. In any case, prudent steps should be taken and fitting organization strategies to be gotten with cooperation among the nations. This can stay as an approach to better relations, remove adversarial vibe among India and Pakistan. Water for this circumstance, should go about as a catalyst for peace. India and Pakistan should continue sharing water delicately for them on the grounds that the two countries are agrarian states and are moving towards genuine water crisis in the coming days. The Indus Water Treaty among India and Pakistan has, paying little heed to undermining political relations between the two countries, stood firm and survived all crisis situation. Along these lines the Treaty has gotten reputation all around as a productive event for battle assurance.

\section{References}

Alam, U. Z. (2002). Questioning the water wars rationale: A case study of the Indus Waters Treaty. The Geographical Journa , 341-353.

Chakraborty, R. A. (2002). Indus Basin Treaty: Its Relevance to Indo-Pak Relations. Pakistan Horizon , 26.

Coscrove, W. R. ( November 1999). World Water Vision: Making Water Everybody's Business,. Newyork: Draft Report: World Commission on Water for the 21th century.

Kalair, A. R. (2019). Water, energy and food nexus of indus water treaty: water governance. Water-Energy Nexus. NewYork: - Elsevier.

Nehru, J. L. (1961). India's Foreign Policy. New Delhi: Publications Division, Government of India.

Schofield, V. (2010). Kashmir in Conflict: India, Pakistan and the Unending War. Bloomsbury Publishing , 232.

Tidwell, A. C. (1998). Conflict Resolved? A Critical Assessment of Conflict Resolution. London: London: Pinter, 1998.

Wolf, A. T. (1999). International river basins of the world. International Journal of Water Resources Development , 387-427. 
INTERNATIONAL JOURNAL OF ACADEMIC RESEARCH IN BUSINESS AND SOCIAL SCIENCES Vol. 9, No. 9, September, 2019, E-ISSN: 2222-6990 @ 2019 HRMARS

File DO 35/8598, Review of developments in Indian economy since Nov 1952, The National Archives, United Kingdom. ${ }^{\text {ii }}$ iii Do 35/8596 Arrangements for publicizing UK participation in Indus Waters scheme (including ceremonial signing of treaty), The National Archives, United Kingdom. See also PREM 11/4305 and DO 118/215, The National Archives, United Kingdom 